\title{
STURGEON (ACIPENSERIDAE BONAPARTE, 1831). THEMATIC ENGLISH LANGUAGE BIBLIOGRAPHY
}

\author{
M. Simon, seemann.sm@gmail.com, Institute of Fisheries NAAS, Kyiv
}

Purpose. Forming a thematic bibliographic list of English-language publications on certain issues of vital activity of sturgeon (Acipenseridae), both in natural conditions and in aquaculture. Particular attention was given to species that are not common in aquaculture of Ukraine.

Methods. The complete and selective methods were applied in the process of the systematic search. The bibliographic core was made up of literary sources from electronic archives of worldrenowned specialized scientific journals. In particular: Journal of Applied Ichthyology, Environmental Biology of Fishes, Conservation Biology, Lake and Reservoir Management, Estuaries, Freshwater Fisheries, Aquaculture, North American Journal of Fisheries Management, Canadian Journal of Fisheries and Aquatic Sciences, Copeia \& others.

Results. A thematic list of main publications including thematic scientific collections, materials of international scientific and practical conferences, scientific articles and abstracts of dissertations was composed. It consists of 187 English-language papers. Presented publications cover the time interval for the last thirty years. The literary sources are arranged in alphabetical order by author or title, and described according to DSTU 8302:2015 "Information and documentation. Bibliographic reference. General principles and rules of composition", with the amendments (code UKND 01.140.40), as well as in accordance with the requirements of APA style - international standard of references.

Practical value. The prepared list may be useful for scientists, practitioners, students, whose sphere of interests is related to issues of questions breeding sturgeon in aquaculture and conservation of populations of rare species of fish.

Key words: sturgeon (Acipenseridae), aquaculture, Acipenser baeri, A. brevirostrum, A. debryanus, A. fulvescens, A. gueldenstaedti, A. medirosris, A. mikadoi, A. naccarii, A. oxyrhynchus, $A$. persicus, A. ruthenus, A. schrenckii, A. sinensis, A. stellatus, A. sturio, A. transmontanus, Huso dauricus, Huso huso.

\section{РИБИ РОДИНИ ОСЕТРОВИХ (ACIPENSERIDAE BONAPARTE, 1831). ТЕМАТИЧНА АНГЛОМОВНА БІБЛІОГРАФІЯ}

\section{М. Ю. Симон, seemann.sm@gmail.com, Інститут рибного господарства НАAН}

України, м. Київ

Мета. Формування довідкового бібліографрічного переліку англомовних публікацій з питань особливостей життєдіяльності риб з родини осетрових (Acipenseridae) як в природних умовах, так і в аквакультурі. Особливу увагу приділено видам, які не є поширеними в аквакультурі України.

Методика. У процесі підготовки тематичного списку, в ході системного пошуку було застосовано цілісний та вибірковий методи. Бібліографічне ядро складали літературні джерела з електронних архівів всесвітньовідомих спеціалізованих наукових журналів зокрема: "Journal of Applied Ichthyology», "Environmental Biology of Fishes», "Conservation Biology», "Lake and Reservoir Management», "Estuaries», "Freshwater Fisheries», "Aquaculture», "North American Journal of Fisheries Management», «Copeia» ma iн.

(C) M. Simon, 2019 
Результати. Сформовано тематичний бібліографічний перелік основних робіт: тематичних наукових збірників, матеріалів міжнародних науково-практичних конференцій, наукових статей $і$ авторефератів дисертацій. Він налічує 187 англомовних джерел. Представлені публікації охоплюють часовий інтервал за останні тридцять років. Літературні джерела розміщені у алфавітному порядку за автором чи назвою, описані згідно з ДСТУ 8302:2015 «/нформація та документація. Бібліографічне посилання. Загальні положення та правила складання», із урахуванням поправок (код УКНД 01.140.40), а також відповідно до вимог оформлення списку літератури за міжнародним стандартом APA style.

Практична значимість. Підготовлений перелік може бути корисним для науковців, практиків, студентів, сфера інтересів яких стосується питань розведення осетрових риб в аквакультурі, а також збереження популяцій зникаючих видів риб.

Ключові слова: осетрові (Acipenseridae), аквакультура, Acipenser baeri, A. brevirostrum, $A$. debryanus, A. fulvescens, A. gueldenstaedti, A. medirosris, A. mikadoi, A. naccarii, A. oxyrhynchus, $A$. persicus, $A$. ruthenus, $A$. schrenckii, A. sinensis, A. stellatus, A. sturio, A. transmontanus, Huso dauricus, $H$. huso.

\section{PЫБЫ СЕМЕЙСТВА ОСЕTРОВЫХ (ACIPENSERIDAE BONAPARTE, 1831). ТЕМАТИЧЕСКАЯ АНГЛОЯЗЫЧНАЯ БИБЛИОГРАФИЯ}

\section{М. Ю. Симон, seemann.sm@gmail.com, Институт рыбного хозяйства НАAН} Украины, г. Киев

Цель. Формирование справочного библиографического перечня англоязычных публикаций по вопросам особенностей жизнедеятельности рыб семейства осетровых (Acipenseridae) как в природных условиях, так и в аквакультуре. Особенное внимание уделено нераспространенным в аквакультуре Украины видам.

Методика. В процессе подготовки тематического списка, в ходе системного поиска были применены целостный и выборочный методы. Библиографическое ядро составляли литературные источники из электронных архивов всемирно известных специализированных научных журналов, в частности: "Journal of Applied Ichthyology», "Environmental Biology of Fishes», "Conservation Biology», "Lake and Reservoir Management», "Estuaries», "Freshwater Fisheries", "Aquaculture», "North American Journal of Fisheries Management», "Copeia» и дp.

Результаты. Сформирован тематический библиографический перечень основных работ: тематических научных сборников, материалов международных научнопрактических конференций, научных статей и авторефератов диссертаций. Он насчитывает 187 англоязычных источников. Представленные публикации охватывают временной интервал за последние тридцать лет. Литературные источники размещены в алфавитном порядке по автору или названию, описаны по ГОСТ 8302:2015 «Информация и документация. Библиографические ссылки. Общие положения и правила составления», с учетом поправок (код УКНД 01.140.40), а также в соответствии с требованиями оформления списка литературы по международному стандарту APA style.

Практическая значимость. Подготовленный перечень может быть полезным для ученых, практиков, студентов, срера интересов которых касается вопросов разведения осетровых рыб в аквакультуре, а также сохранения популяций редких видов рыб.

Ключевые слова: осетровые (Acipenseridae), аквакультура, Acipenser baeri, $A$. brevirostrum, A. debryanus, A. fulvescens, A. gueldenstaedti, A. medirosris, A. mikadoi, A. naccarii, $A$. oxyrhynchus, $A$. persicus, A. ruthenus, A. schrenckii, A. sinensis, A. stellatus, A. sturio, $A$. transmontanus, Huso dauricus, $H$. huso. 
1. A brief overview on the status and prospects of sturgeon farming in Western and Central Europe / Bronzi P. et al. // Journal of Applied Ichthyology. 1999. Vol. 15. P. 224-227.

2. Abdolhay H., Tahori H. B. Fingerling production and stock enhancement of Sturgeon in South of the Caspian Sea // 3rd International symposium on Sturgeon, Piacenza, Italy, 1997. July 8-11 : booklet of abstracts. Piacenza, 1997. P. 298.

3. Ability of juvenile white stutgeon (Acipenser transmontanus) to utilize different carbohydrate sources / Hung S. O. et al. // The Journal of Nutrition. 1989. Vol. 119. P. 727-733.

4. Amaoka K., Nakaya K. First record of Caluga Sturgeon (Huso dauricus), from Japan // Japanese Journal of Ichthyology. 1975. Vol. 22. P. 164-166.

5. Induced breeding of the Italian sturgeon (Acipenser naccarii) raised in captivity / Arlati G. et al. // Riviy Italy Acquacoltore. 1998. Vol. 23. P. 94-96.

6. Arlati G., Grassi A., Granata A. Restocking Lombardian region rivers with the anadromous Adriatic sturgeon (Acipenser naccarii) // 3rd International symposium on Sturgeon, Piacenza, Italy, 1997. July 8-11 : booklet of abstracts. Piacenza, 1997. P. 47.

7. Artificial reproduction and larval rearing of captive endangered Atlantic sturgeon (Acipenser sturio) / Williot P. et al. // Endangered Species Research. 2009. Vol. 6. P. 251-257.

8. Artificial spawning and aquaculture of Amur sturgeon / Sun D. J. et al. Beijing, China : China Ocean press, 2003.96 p.

9. Aspects of early development in the Adriatic sturgeon (Asipenser naccarii) / Boglione C. et al. // Journal of Applied Ichthyology. 1999. Vol. 15. P. 207-213.

10. Auer N. A. Effects, of change, in operation of a small hydmekctrie facility on spawning characteristics of lake sturgeon // Lake and Reservoir Management. 1994. Vol. 9. P. 52-53.

11. Bacalbasa-Dobrovici N. Saving of Romanian sturgeon needs a consequent strategy and tactics //Analele Atiintifice ale Institutului-Delta Dunarii. 1993. P. 221-226.

12. Bachmani M., Kazemi R., Donskaya P. A comparative study of some hematological features in young reared sturgeons (Acipenser persicus and Huso huso) // Fish Physiology and Biochemistry. 2001. Vol. 24. P. 135-140.

13. Badino G., Maiorana G., Montorio L. Growth juveniles of Italian sturgeon (Acipenser naccarii Bonaparte) // Recreational sympos. on sturgeon, Piacenza, Italy 1997, July 8-11 : book of abstracts. Piacenza, 1997. P. 74-77.

14. Bain M. Atlantic and shortnose sturgeons of the Hudson River: common and divergent life history attributes // Environmental Biology of Fishes. 1997. Vol. 48. P. 347-358.

15. Beamesderfer R. C. P., Rien T. A., Nigro A. A. Differences in the dynamics and potential production of impounded and unimpounded white sturgeon populations in the Lower Columbia River // Transactios of the American Fisheries Society. 1995. Vol. 124. P. 857-872.

16. Beamesderfer R. C. P., Farr R. A. Alternatives for the protection and restoration of sturgeos and their habitat // International Conference on Sturgeon Biodiversity and Conservation : proceedings. New York, 1994.

17. Beamish W. E., William H. Growth strategy of juvenuile lake sturgeon (Acipenser fulvescens) in a northern river // Canadian Journal of Fisheries and Aquatic Sciences. 1996. Vol. 53. P. 481-489.

18. Beamihs W. E., Findeis E. K., Grande L. An overview of Acipenseriformes // Environmental Biology of Fishes. Vol. 48. P. 25-71. 
19. Bean-Knudsen E. D., Uhazy L. S., Wagner J. E. Cranial chondrosarcoma in a paddlefish (Polyodon spathula Walbaum) // Journal of Fish Diseases. 1987. P. $363-369$.

20. Biology and life history of Dabry sturgeon (Acipenser debryanus) / Zyuang P. et al. // Internat. conf. on sturgeon biodiversity and conservation : proceedings. 1996. Vol. 4. P. 286-292.

21. Biology, fisheries, and conservation of sturgeons and paddlefish in China / Wei Q. et al. // Environmental Biology of Fishes. 1997. Vol. 48. P. 241-255.

22. Biology and conservation of the European Sturgeon Acipenser sturio L. 1758: The Reunion of the European and Atlantic Sturgeons / eds. Williot P. et al. Springer Science \& Business Media, 2011. 668 p.

23. Birstein V. J., Bemis W. E. Leo Semenovich Berg and the biology of Acipenseriformes: a dedication // Environmental Biology of Fishes. 1997. Vol. 48. P. $15-22$.

24. Birstein V. J. Sturgeons may soon disappear from the Caspian Sea // Russian Conservation News. 1996. Vol. 7. P. 15-16.

25. Birstein V. J., Bemis W. Endangered Status // The Sturgeon Quarterly. 1995. Vol. 3. P. 1-12.

26. Birstein V. J. Sturgeons and Paddlefishes: Threatened fishes in need of conservation // Conservation Biology. 1993. Vol. 7. P. 773-787.

27. Bramick U. Sturgeon in the pond-fish farm // Fischer und teichwirt. 1992. Vol. 43. P. 7-9.

28. Bruch R. M., Miller G., Hansen M. G. Fecundity of Lake Sturgeon (Acipenser fulvescens Rafinisque) in Lake Winnebago, Wisconsin, USA // Journal of Applied Ichthyology. 2006. Vol. 22. P. 116-118.

29. Bruch R. M. Management of lake sturgeon on the Winnebago System - long term impacts of harvest and regulations on population structure // Journal of Applied Ichthyology. 1999. Vol. 15. P. 142-152.

30. Bruch R. M. Management and trade of Lake Sturgeon in North America // Symposium on the Harvest, Trade and Conservation of North American Paddlefish and Sturgeon : proceedings. Chattanooga, Tennesee, 1998. 96 p.

31. Brundaqe H. M., Meadows R. E. Occurrence of the endangered Shortose sturgeon, (Acipenser brevirostrum) in the Delaware River estuary // Estuaries. 1982. Vol. 5. P. 203-208.

32. Buddington R. K. Digestive secretions of lake sturgeon (Acipenser fulvescens), during early development // Journal of Fish Biology. 1985. Vol. 26. P. 715-723.

33. Burggren W. W. Gill ventilation in the sturgeon, unusal adaptations for bottom dwelling // Respiratory Physiology \& Neurobiology. 1978. Vol. 34. P. 153-170.

34. Cardiovascular responses to hypoxia in the Adriatic sturgeon (Acipenser naccarii) / Agnisola C. et al. // Journal of Applied Ichthyology. 1999. Vol. 15. P. 6-7.

35. Cech J. J., Mitchill S. J., Wragg T. E. Comparative growth of juvenile with sturgeon and stripped bass: effects of temperature and hipoxia // Estuaries. 1984. Vol. 7. P. 12-18.

36. Celikkale M. S., Memis D., Ercan E. Growth performance of juvenile Russian sturgeon (Acipenser gueldenstaedti Brandt \& Ratzenburg, 1983) at two stocking densities in net cages // Journal of Applied ichthyology. 2005. Vol. 21. P. 14-18.

37. Ceskleba D. G. S., Thuemler T. F. Artificial spawning and rearing of Lake Sturgeon (Acipenser fulvescens) in Wild Rose Fish Hatchery, Wisconsin, 1982-1983 // Environmental Biology of Fishes. 1985. Vol. 14. P.79-85. 
38. Chang J. Immersion marking of larval Chinese sturgeon (Acipenser sinensis), with alizarin // Journal of Applied Ichthyology. 1999. Vol. 15. P. 238-243.

39. Chapman F. A., Van Eenennaam J. R., Doroshov S. I. The reproductive condition of white sturgeon (Acipenser transmontanus) in San Francisco Bay, California // Fishery Bulletin. 1996. Vol. 94. P. 628-634.

40. Charlon N., Bergot P. Artifical feeding of Siberian stergeon // Acipenser Actes ler Collog international Esturgeon, Bordeaux, 3-6 oct. 1989. Bordeaux, 1991. P. 405- 415.

41. Collins M. R., Smith T. J., Heyward L. D. Effectiveness of six methods for marking juvenile shortnose sturgeons // The Progressive Fish-Cufturist. 1994. Vol. 56. P. $250-254$.

42. Culture and stock enhancement of shornose sturgeon and Atlantic sturgeons / Collins M. R. et al. // Bull. Nation. Res. Inst. Aquacult. 1999. P. 101-108.

43. Czeczuga B. Content of carotenoids in eggs utilized in the form of caviar // Folia Histochemica Et Cytochemica. 1982. Vol. 20. P. 63-68.

44. Czeczuga B. Carotenoids in the eggs of Acipenser ruthenus L. (Acipenseridae) from the Danube // Hidrobiologia. 1971. Vol. 39. P. 9-16.

45. Dabrowski K., Kausik S. J., Fauconean B. Rearinng of sturgeon (Acipenser baeri Brandt) larvae // Aquaculture. 1985. Vol. 47. P. 17-29.

46. Dadswell M. J., Potte R. A. Locomotor behaviour and preliminary assesmrat of critical swimming speeds for juvenil sturgeon Acipenser brevirostrum and Acipenser oxyrhynchus. // 113-th Ann. meeting of the Americsn Fisheries Society: abstr. 1983. P. 105-106.

47. Dadswell M. J. Biology and population characteristics of the shortnose sturgeon (Acipenser brevirostrum LeSeur 1818), in the Saint John river estuary, NewBrunswick, Canada // Canadian Journal of Zoology. 1979. Vol. 57. P. 2186-2210.

48. Debus L. When the American sea sturgeon swam east (A colder Baltic Sea greeted this fish from across the Atlantic Ocean in the Middle Ages) // Nature. 2002. Vol. 419. P. 447-448.

49. Debus L., Groger J. Morphometry comparison of Acipenser sturio L. populations based on mixed estimation and morphometric measurements // Archive of Fishery and Marine Research. 2000. Vol. 48. P. 175-193.

50. De Melenaer T., Raymakers C. Sturgeons of the Caspian Sea and the international trade in caviar // TRAFFJC International. 1996. P. 71.

51. Determination of sex and maturity in sturgeon (Acipenser stellatus) by using ultrasonography / Mogxim M. et al. // Journal of Applied Ichthyology. 2002. Vol. 18. P. 325-328.

52. Determination of optimal feed rations for Siberian sturgeon (Asipenser baeri) kept in cooling water / Sadowski J. et al. // Falia Univ. Agrie. Stetin. 2000. Vol. 214. P. 193-199.

53. Development and identification of larval Atlantic sturgeon (Acipenser oxyrhynchus) and shortnose sturgeon (A. brevirostrum) from the Hudson River Estuary, New York / Bath D. et al. // Copeia. 1981. Vol. 3. P. 711-717.

54. Domestication and biology of Amur sturgeon (Acipenser schrenckii) in central China: I. Growth of young-of-the-year / Zhuang P. et al. // Freshwater Fisheries. 1998. Vol. 28. P. 6-9.

55. Doroshov S. I., Moberg G. P., Van Eenennaam J. P. Observations on the reproductive cycle of cultured white sturgeon (Acipenser transmontanus) // Environmental Biology of Fishes. 1997. Vol. 48. P. 265-278.

56. Doroshov S. I., Lutes P. B. Preliminaty data on the induction of ovulation in white 
sturgeon (Acipenser transmontanus Richardson) // Aquaculture. 1984. Vol. 30. P. $221-227$.

57. Dynamics and potential production of White Sturgeon in the unimpounded lower Columbia River / De Vore J. D. et al. // Transactions of the American Fisheries Society. 1995. Vol. 124. P. 845-856.

58. Ebrahimi E. Determination of the best time to transfer Beluga (Huso huso) juveniles from natural to commercial diets // Journal of Applied Ichthyology. 2006. Vol. 22. P. 274-277.

59. Ebrahimi E., Zare P. Growth and survival of Beluga (Huso huso) and Persian sturgeon (Acipenser persicus) fingerlings fed by live food and artificial diet // Journal of Applied Ichthyology. 2006. Vol. 22. P. 321-324.

60. Echols J. E. Fraser River Action Plan Fishery Management Group. Review of Fraser River White Sturgeon (Acipenser transmontans) // Vancover, B. C. : Department of Fisheries and Oceans, 1995. 33 p.

61. Effects of diet on spontaneous locomotor activity and oxygen consumption in Adriatic sturgeon (Acipencer naccarii) / Mc Kenzie D. J. et al. // Fish Physiology \& Biochemistry. 1995. Vol. 14. P. 341-355.

62. Elvira B., Almodovar A. Notice about the survival of sturgeon (Acipencer sturio L., 1758) in the Guadalquivir estuary (S. W. Spain) // Archiv fur Hydrobiologie. h. 1993. Vol. 129. P. 253-255.

63. Fahim H. R. Breeding and mass production of sturgeons // Zetoun magazine. 1991. Vol. 103. P. 174-183.

64. Fange R. Lymphoid organs in sturgeons (Acipenseridae) // Veterinary Immunology and Immunopathology. 1986. Vol. 12. P. 153-161.

65. Fashtomi H. R. P., Mohseni M. Survival and growth of larval and juvenile Persian sturgeon (Acipenser persicus) using formulated diets and live food // Journal of Applied Ichthyology. 2006. Vol. 22. P. 303-306.

66. Female Siberian sturgeon (Acipenser baeri): an interesting model for reproductive physiology studies in fish / Le Menn F. et al. // Journal of Applied Ictiology. 1999. Vol. 15. P. 315-316.

67. Gessner J., Hochleithner M. The sturgeons and Paddlefishes (Acipenseriformes) of the World // Biology and Aguaculture : Austria, 1999. 165 p.

68. European-wide coordination trial for programmes to save the common sturgeon Acipenser sturio L.) / Gessner J. et al. // 3rd International symposium on Sturgeon, Piacenza, Italy, 1997. July 8-11 : booklet of abstracts. Piacenza, 1997. P. 28.

69. Gilbert C. R. Atlantic sturgeon. Gainesville : University Presses of Florida, 1992. Vol. II: Fishes. P. 5-8.

70. Gisbert E., Williot P., Castello-Orvay F. Influence of egg size of sibirian sturgeon (Acipenser baeri) under small scale hatchery conditions // Aquaculture. 2000. Vol. 183. P. 83-94.

71. Gisbert E., Williot P. Larval behaviour and effect of the timing of initial feeding on growth and survival of Siberian sturgeon larvae under small scale hatchery production // Aquaculture. 1998. Vol. 52. P. 54-62.

72. Gisbert E., Williot P. Behavioural reactions of Siberian sturgeon (Acipenser baeri, Brandt) to different modifications of environmental rearing conditions during early ontogeny // Journal of Fish Biology. 1997. Vol. 50. P. 100-138.

73. Gonadal maturity of wild sturgeons Huso dauricus, Acipenser mikadoi and A. schrenckii caught near Hokkaido, Japan / Omoto N. et al. // Enviromental Biology of Fishes. 2004.Vol. 70. P. 381-391. 
74. Grandi M. Chicca D. Early development of the pituitary gland in Acipenser naccarii (Chondrostei, Acipenseriformes): an immunocytochemical study // Anatomy and Embryology. 2004. Vol. 208. P. 310-321.

75. Groger J., Debus L. Morphometric comparison of Acipenser sturio L. populations based on mixed estimation and morphometric measurements // Archive of Fishery Marine Research. 2000. Vol. 48 P. 175-193.

76. Growth of hatohery-produced juveniles of Italian sturgeon (Acipenser nacarii Bonaporte) reared intensively in fresh water / Giovanni G. et al. // Acipenser. Prem. Col-Intern. L'Esturg., Bordeaux. Cemagref, 1989. P. 401- 415.

77. Hall J. W., Smith T. J., Lamprecht S. D. Movements and habitats of shortnose sturgeon (Acipencer brevirostrum) in the Savannah River // Copeia. 1991. Vol. 3. P. 695-702.

78. High-energy diets for white sturgeon (Acipenser transmontanus Richardson) / Hung S. O. et al. // Aquaculture Nutrition Vol. 3. 1997. P. 281-286.

79. Hjul P. French farms now ready with the Fish of Kings // Fish Farming Internaional. 1996. Vol. 23. P. 32-33.

80. Hochleithner M., Gessner J. The sturgeons and paddlefishes of the world biology and aquaculture. Kitzbuehl, Austria : AquaTech Publications, 2001. 207 p.

81. Honma Y., Itano H. A record of Great Siberian Sturgeon (Huso dauricus) off Niigata, Sea of Japan // Japanese Journal of Ichthyology. 1994. Vol. 31. P. 317-321.

82. Hormone-induced ovulation and artificial spawning of Gulf of Mexico sturgeon (Acipenser oxyrhynchus desotoi) / Parauka F. M. et al. // Progress. Fish Culturist. 1991. Vol. 53. P. 113-117.

83. Horvath L., Peteri A., Kouril J. Successfal sterlet (Acipenser ruthenus L.), propagation with synthetic LH-RH hormone // Aquaculture and fish managment 1986. Vol. 17. P. 113-116.

84. Hossain A. Fingerling prodaction and stock enhancement of sturgeon in south of Caspian sea // 3rd International symposium on Sturgeon, Piacenza, Italy, 1997. July 8-11 : booklet of abstracts. Piacenza, 1997. P. 21-23.

85. Houston J. J. P. Status of the Green Sturgeon (Acipenser medirosris) in Canada // The Canadian Field Naturalist. 1988. Vol. 102. P. 286-290.

86. Houston J. J. P. Status of the lake sturgeon (Acipenser fulvescens) in Canada // The Canadian Field Naturalist. 1987. Vol. 102. P. 171-185.

87. Hung S. O., Conte F., Lutes P. B. Optimal retion of white sturgeon at commercial rearing // Journal of Applied Aquaculture. 1995. Vol. 1. P. 45-51.

88. Hung S. O., Fynn-Aikins F. K. Carbohydrate utilization and its impact on some metabolic and histological parameters in wait sturgeon // Fish nutrition in practice : IV intern. symp. on fish nutrition and feeding : proceedings. Paris : INRA, 1993. P. 15.

89. Induced spermiation in 3-year-old sterlet, Acipenser rutnenus L. / Rzemieniecki A. et al. // Aquaculture Research. 2004. Vol. 35. P. 144-151.

90. Influences on tissue lipid quality of the sturgeon (Asipenser naccari) from intensive culture / Garsia-Gallego M. et al. // 3rd International symposium on Sturgeon, Piacenza, Italy, 1997. July 8-11 : booklet of abstracts. Piacenza, 1997. P. 80-81.

91. Influence of sampling conditions on blood chemistry values of Adriatic sturgeon (Acipenser naccarii Bonaparte, 1836) / Di Marco P. et al. // Journal of Applied Ichthyology. 1999. Vol. 15. P. 73.

92. Jiang L.-F. Effects of ecologic environmental pollution on Chinese sturgeon (Acipenser sinensis) // 3rd International symposium on Sturgeon, Piacenza, Italy, 
1997. July 8-11 : booklet of abstracts. Piacenza, 1997. P. 207-208.

93. Jose L. O., Jose M. I., Domezain A. Corpuscle of the sturgeon kidney: an ultrastructural, chemical dissection, and lectin-binding study // The Anatomical Record. 2003. Vol. 2. P. 563-573.

94. Keenlyne K. D., Maxwell S. J. Length conversions and length-weight relations for pallid sturgeon // North American Journal of Fisheries Managemnt. 1993. Vol. 13. P. 395-397.

95. Kempinger J. J. Spawning and early life history of lake sturgeon in the Lake Winnebago system, Wisconsin // American Fisheries Society Symposium. 1988. Vol. 5. P. $110-122$.

96. Kempinger J. J. Habitat, growth and food of Young Lake Sturgeon in the Lake Winnebago System, Wisconsin // North American Journal of Fisheries Management. 1996. Vol. 16. P. 102-114.

97. Kennedy A. J., Sutton T. M., Fisher B. E. Reproductive biology of female shovelnose sturgeon in the upper Wabash River, Indiana // Journal of Applied Ichthyology. 2006. Vol. 22. P. 177-182.

98. Kieffer M., Kinard B. Annual movements of shortnose and Atlantic sturgeons in the Merrimack River, Massachusetts // Transactions of the American Fisheries Society. 1993. Vol. 122. P. 1088-1103.

99. Kime D. E., Lambert J. G., Bukovskaya O. V. Steroid synthesis by gonads of the Russian sturgeon (Acipenser gueldenstaedti) // Annual Endocrinology. 1996 Vol. 57. P. $4-22$.

100. Kohlhores D. W. Sturgeon spawning in the Sacramento river in 1973, as determined by distribution of larvae // Californian Fish and Game. 1976. Vol. 62. P. $80-86$.

101. Kurfurst J., Kerber P., Kakous L. Growth of Siberian sturgeon (Acipenser baerii) in the Czech Republics conditions // Czech Journal of Animal Sciences. 2000. Vol. 45. P. $545-552$

102. Linares-Casenave J., Van Eenennaam J. P., Doroshev S. I. Ultrastructural and histological observations on temperature induced follicular ovarian in the white sturgeon // Journal of Applied Ichthyology. 2002. Vol. 18. P. 382-390.

103. Logan S. H., Johnston W. E., Doroshov S. I. Economics of joint production of sturgeon (Acipenser transmontanus Richardson) and roe for caviar // Aquaculture. 1995. Vol. 12. P. 299-316.

104. Loy A., Bronsi P., Molteni S. Geometric morphomertric in the characterization of the cranial growth pattern of Adriatic sturgeon (Acipenser naccarii) // Journal of Applied Ictiology. 1999. Vol. 15. P. 1-50.

105. Lutes P. B. Oocyte maturation in white sturgeon (Acipenser transmontanus): some mechanisms and applications // Environmental Biology of Fishes. 1985. Vol. 14. P. 87-92.

106. Marking of sturgeon Acipenser sturio L. alevins dedtined for restocking / Brun R. et al. // 3rd International symposium on Sturgeon, Piacenza, Italy, 1997. July 8-11 : booklet of abstracts. Piacenza, 1997. P. 4-7.

107. May den R. L., Kuhajda B. R. Systematics, taxonomy, and conservation status of the endangered Alabama sturgeon (Scaphirhynchus suttkusi William and Clemmer (Actinopteiygii, Acipenseridae)) // II Copeia. 1996. Vol. 1996. P. 241-275.

108. Mc Cade G. T, Gejrge T., Tracy C. A. Spawning and early life history of white stugeon (Acipenser transmontanus), in the lower Columbia river // Fisheries Bulletin. 1994. Vol. 92. P. 760-772. 
109. Mc Cade G. T., Emmett R. L., Hinton S. A. Feeding ecology of juvenile white sturgeon (Acipenser transmontanus) in lower Columbia River // Northwest Science. 1993. Vol. 67. P. 170-180.

110. Mc Cade G. T., Pried S., Towt A. Daili movements of short nose sturgeon (Acipenser brevirostrum) in a Maine estuary // Copeia. 1977. Vol. 1. P. 149-157.

111. Mc Enroe M., Cech J. J. Osmoregulation in juvenile and adult White sturgeon, (Acipenser transmontanus) // Environmental Biology of Fishes. 1985. Vol. 14. P. $23-30$.

112. Meulenaer T., Raymaker C. Sturgeons of the Caspian Sea and the international trade in caviar // TRAFFJC International. 1996. P. 71.

113. Mohler J. W. Feeding trials with juvenile atlantic sturgeons propagated from wild broodstock // Progr. Fish.-Cult. 1996. Vol. 58. P. 173-177.

114. Moos R. E. Movement and reproduction of shovenose sturgeon (Scaphirynchus platoiynehus) in the Missouri River, South Dakota : Ph. Dissertation. Vermillion : University of South Dakota, 1978. 216 p.

115. Mims S. D. Will the Chinese Paddlefish Survive? // Sturgeon Quarterly. 1995. Vol. 3. P. 1-12.

116. Morphometric comparisons of upper Missouri River sturgeons / Keenlyne K. D. et al. // Transactions of the American Fisheries Society. 1994. Vol. 123. P. 779-785.

117. Nagy S. The food of sterlet (Acipenser ruthenus L.) in the czechoslovar-ungarian section of the Danube // Folia zoologica. 1987. P. 281-287.

118. National Paddlefish and Sturgeon Steering Committee (NPSSC). Framework for the management and conservation of paddlefish and sturgeon species in the United States. 1993. $41 \mathrm{p}$.

119. Navodaru I., Stara M., Banks R. Management of sturgeon stocks of the lower Danube River system // The Delta's: State-of-art protection and management: confrence, Tulcea, Romania, 26-31 July 1999 : proceedings. P. 229-237.

120. Nonconcordant evolutionary history of maternal and paternal lineages in Adriatic sturgeon / Ludwig A. et al. // Molecular ecology Resources. 2003. Vol. 12. P. 3253-3264.

121. North American Sturgeons: Biology and Aquaculture Potential / eds. Binkowski F. P., Doroshov S. I. The Netherlands, Dordrecht : Dr. W. Junk Publishers, 1985. 167 p.

122. North J. A., Beamesderfer R. C., Rien T. A. Distribution and movements of white sturgeon in three lower Columbia River reservoirs // Northwest Science. 1993. Vol. 67. P. 105-111.

123. Occurence and in vitro biosynthesis of 11-ketotestosterone in Siberian sturgeon, (Acipenser baeri Brandt) maturing females / Cuisset B. et al. // Fish Physiology \& Biochemystry. 1995. Vol. 14. P. 313-322.

124. Occurrence of stocked shortnose sturgeon (Acipenser brevirostrum) in non-target rivers / Smith T. J. et al. // Journal of Applied Ichthyology. 2002. Vol. 18. P. 470- 474.

125. Overview of biology and aquaculture Amur sturgeon (Asipenser schrenckii) in China / Zhuang P. et al. // Journal of Applied Ichthyology. 2002.Vol. 18. P. 659-664.

126. Paaver T. A. Common or Atlantic sturgeon (Acipenser sturio), was cought in the Estonian waters of the Baltic sea // The Sturgeon Quarterly. 1996. Vol. 4. P. 1-7.

127. Parauka F. M. Guidelines for artificially spawning Gulf sturgeon. Florida, USA, 1993. $29 \mathrm{p}$.

128. Pecheanu C. T., Vasile M., Patriche N. Some results of artificial propagation of Acipenser stellatus at the Brates hathery, Galati // Ananele Atiintifice ale Institutului-Delta Dunarii. 1993. P. 169-170. 
129. Ping Z., Jifang Y. Sturgeon and paddlefish aquaculture in China // 3rd International symposium on Sturgeon, Piacenza, Italy, 1997. July 8-11 : booklet of abstracts. Piacenza, 1997. P. 399.

130. Poliakova L., Artaly G., Giovannini J. The use of the synthetic hormone LH-RH (d-ala6) for reproductive control of wild caught and captivity raised sturgeons // 4th International Symposium on sturgeon : proceedings. Oshkosh, Wisconsin, USA, 2001. P. 160.

131. Potential for egg extraction from female sturgeon spawners through key-hole surgery / Parandavar H. et al. // Journal of Applied Ichthyology. 2006. Vol. 22. P. 287-290.

132. Potts W. T. W., Rudy P. P. Aspects of osmotic and ionic regulation in the sturgeon // Journal of Experimental Biology. 1972. Vol. 56. P. 703-715.

133. Priegel G. R. Lake sturgeon management on the Menominee River// Wic. Dep. Nat. Resour. : Technical bulletin. 1973. Vol. 67. 20 p.

134. Prokes M., Barus V., Penaz M. Morphometrical analysis of $0+$ juvenile giant sturgeon (Huso huso) rearing in the Czech republic for first time // Folia zoological. 1995. Vol. 44. P. 269-278.

135. Purification and characterization of the hemoglobin components of Adriatic sturgeon (Acipenser naccarii) blood / Clementi M. E. et al. // Journal of Applied Ichthyology. 1999. Vol. 15. P. 7-8.

136. Rasuli M. Sturgeons, suitable species for breeding and rearing // Abjiyan magazine. 1991. Vol. 16. P. 70-72.

137. Raymakers C. CITES, the Convention on International Trade in Endangered Species of Wild Fauna and Flora: its role in the conservation of Acipenseriformes // Journal of Applied Ichthyology. 2006. Vol. 22. P. 53-65.

138. Raymakers C., Hoover C. Acipenseriformes: CITES impementation from Range States to consumer countries // Journal of Applied Ichthyology. 2002. Vol. 18. P. 629-638.

139. Rieman B. E., Beamesderfer R.C . White sturgeon in lower Columbia River: Is the stock overexploited? // North American Journal of Fisheries Management. 1990. Vol. 10. P. 388-396.

140. Reproductive isolation in sympatric populations of pallid and shovelnose sturgeon / Tranah G. J. et al. // North American Journal of Fisheries Management. 2001. Vol. 21. P. 367-373.

141. Ronyal A., Csengeri I., Varadi L. Partial substitution of animal protein with full-fat soybean meal and amino acid supplement in the diet of Siberian sturgeon (Asipenser baeri) // Journal of Applied Ichthyology. 2002. Vol. 19. P. 682-684.

142. Ronyal A. Effect of food ration and water temperature on growth of juvenile Siberian sturgeon (Acipenser baerii) // Journal of Applied Ichthyology. 1998. Vol. 15. P. 344-345.

143. Rossiter A., Noakes D. L., Beamish E. W. Validation of the Age Estimation for the Lake Sturgeon // Transactions of the American Fisheries Society. 1995. Vol. 124. P. 777-781.

144. Roussow G. Some considerations concerning sturgeon spawning periodicity // Jornal of fisheries research Board of Canada. 1957. Vol. 14. P. 553-572.

145. Sangalang G. B., Weisbart M., Idler D. R. Steroids of a chondrostean: corticosteroids and testosterone in the plasma of the american atlantic sturgeon, (Acipenser oxyrhynchus Mitchill) // Journal of Endocrinology. 1971. Vol. 50. P. 413-421. 
146. Sheibani M. T. A histological study on some organ tissues involved in the immune system of Acipenser persicus // Agriculture and Natural Resources : 3rd International Iran and Russia Conference, sept. 2002 : abstracts. Moscow : MTAA, 2002. P. 159.

147. Smith T. J., Collins M. R. Shortnose sturgeon stocking success in Savannah River // Ann. Conf. Southeast Assoc. : proceedings. Fish and Wildl. Agencies 50, 1996. P. $112-121$.

148. Smith T. J. Culture of North American sturgeons for fishery enhancement // PNOAA Technical Reptort NMFS. 1990. Vol. 85 P.19-27.

149. Smith T. J., Oldland W., Jenkins W. E. Development of nursery systems for shorttnose sturgeon (Acipenser brevirostrum) // Ann. Conf. Southeast. Ass. : proceedings. Fish \& Wildlife Agencies. 1988. Vol. 140. P. 143-151.

150. Smith T. J., Dingley E. K., Marchette D. E. Induced spawning and culture of the Atlantic sturgeon (Acipenser oxyrhynchus) // Progres. Fish-Culturist. 1980. Vol. 42. P. 147-151.

151. Some aspects of osmotic and ionic regulation in Adriatic sturgeon: Ontogenesis of salinity tolerans / Cataldi E. et al. // Journal of Applied ichthyology. 1997. Vol. 15. P. $61-65$.

152. Spawning and culture of shortnose sturgeon (Acipenser brevirostrum) / Smith T. J. et al. // World Mariculture Society. 1985. Vol. 16. P. 104-113.

153. Spirulina as a nutrient source in diets for growing sturgeon (Acipenser baeri) / Palmegiano G. B. et al. // Aquaculture Research. 2005. Vol. 36. P. 188.

154. Status of sturgeon aquaculture and sturgeon trade in China: a review based on two recent nationwide surveys / Wei Q. et al. // Journal of Applied Ichthyology. 2004. Vol. 20. P. 321-332.

155. Status and prospects of sturgeon farming in Western Europe / Bronzi P. et al. // 3rd International symposium on Sturgeon, Piacenza, Italy, 1997. July 8-11 : booklet of abstracts. Piacenza, 1997. P. 121-123.

156. Steffens W., Jahnichen H., Fredrich F. Possibilities of sturgeon culture in Central Europe // Aquaculture. 1990. Vol. 89. P. 101-117.

157. Stevens D. E. Distribution of sturgeon larvae in the Sacramento San Joaguin river system // Californian Fish and Game. 1970. Vol. 56. P. 80-86.

158. Stock enhancement of shornose sturgeon: a case study / Smith T. J. et al. // Transaction of American Fisheries Society. 2002. Vol. 28. P. 31- 44.

159. Studies of morpho-phenotypes of stellate sturgeon (Acipenser stellatus) from the Brates farm-Galati / Statescu M. et al. // Analele Atiinfice ale Institutului-Delta Dunarii. 1993. P. 185-188.

160. Sturgeon biodiversity and conservation / eds. Birstein V. J., Waldman J. R., Bemis W. E. London : Kluwer Academic Publishers, 2002. 445 p.

161. Sturgeon distribution in Italy / Bronzi P. et al. // International Conference on Sturgeon Bidiversity and Conservation : proceedings. New York, 1996. P. 32-36.

162. Synopsis of biological data on shortnose sturgeon (Acipenser brevirostrum, LeSueur 1818) / Dadswell M.J. et al. // FAO Fisheries Synopsis. 1984. 140 p.

163. Taylor S. The historical development of the caviar trade and industry // Sturgeon stocks and caviar trade : German workshop : proceedings. Bonn, 1996. P. 121-134.

164. The culture of Amur sturgeon (Acipenser schrenki) at different feed rates / Zhao Li-Wei et al. // Journal Fisheries Sciences of China. 2004. Vol. 11. P. 375-378.

165. The resource situation of sturgeons in the Heilongjiang River / Sun D. J. et al. // Technical compendium to the proceedings of 4th international Symposium on 
Sturgeon. Wisconsin : Sea Grant University of Wisconsin, 2002. P. 1-6.

166. The effect of sturgeon density on manifestation of white sturgeon iridovirus disease / La Patra S. E. et al. // Journal of Applied Aquaculture. 1996. Vol. 6. P. 51-58.

167. The Siberian Sturgeon (Acipenser baerii, Brandt, 1869) / eds. Williot P. et al. // Springer International Publishing, 2018. 780 p.

168. Thuemler T. F. Lake Sturgeon management in the Menominee River, a Wisconsim-Michigan Boundary Water // International Conference on Sturgeon Biodiversity and Conservation : proceedings. New York, 1996. P. 82-93.

169. Tortonese E. Acipenser naccarii Bonaparte $1836 / /$ The Freshwater Fishes of Europe. Vol. 1/2 : General Introduction of Fishes. Acipenseriformes. Wiesbaden : AULA-Verlag, 1989. P. 285-293.

170. Unusual conditions for Siberian sturgeon (Aipenser baerii Brandt) spawning / Vizziano D. et al. // Journal of Applied Ichthyology. 2016. Vol. 22. P. 325-330.

171. Vaisman A., Raymakers C. The Status of Sturgeon resources in Russia // TRAFFIC Bulletin. 2001. Vol. 19. P. 33- 44.

172. Vasile M., Pecheanu C., Patriche N. Some results of superintensive raising technology of Acipenser stellatus // Analele Atiintifice ale Institutului-Delta Dunarii. 1993. P. 385-386.

173. Varadi L., Ronyai A. The history, current research and future potential of sturgeon culture in Hungary // Journal of Applied Ichthyology. 1999. Vol. 15. P. 329-330.

174. Vecsei P., Charette R., Hochleithner M. Guide to the Identification of Sturgeon and Paddlefish Species Controlled under the Convention on International Trade in Endangered Species of Wild Fauna and Flora. Ottava : CITES. 2004. P. 30-33.

175. Waldman J. R., Wirgin I. Status and restoration options for Atlantic sturgeon in North America // Ecology and Conservation Biology. 1998. Vol. 12. P. 631-638.

176. Wang Y. L., Chang J. L. Status and conservation of sturgeons in Amur River, China: a review based on surveya sinse the year 2000 // Journal of Applied Ichthyology. 2006. Vol. 22. P. 44-52.

177. Wang Y. L., Buddington R. K., Doroshov S. I. Influence of temperature on yolk utilization by the white sturgeon (Acipenser transmontanus) // Journal of Fish Biology. 1987. Vol. 30. P. 263-271.

178. Weber W., Jenning C. A., Rogers S. G. Population size and movement patterns of shortnose sturgeon in the Ogeechee River system, Georgia // Ann. Conf. Southeast Assoc. : proceedings. Fish and Wildl. Agencies. 1998. Vol. 52. P. 18-28.

179. Webb M. A., Doroshov S. I., Van Eenennaam J. P. Effects of temperature on final ovarian maturation in white sturgeon (Acipenser transmontanus) // Intern. Fish. Physiol. Symp. Fish Physiol. Ass. : proceedings. Vancouver (Canada), 1994. P. $186-190$.

180. Williot P., Bronsi P., Arlati G. A very brief survey of status and prospects of freshwater sturgeon farming. Ghent, Belgium : EAS, Spesial Publication, 1999. Vol. 20. P. 32-36.

181. Williot P. Attempts at larval rearing of the endangered western European Strugeon, (Acipenser sturio) in France // Cybiun. 2005. Vol. 29. P. 381-387.

182. Williot P., Arlati G., Chebanov M. S. Status and management of Eurasian sturgeon: overview // International Review of Hydrobiology. 2002. Vol. 87. P. 483-506.

183. Williot P., Brun R. Ovarian development and cycles in cultured Siberian sturgeon (Asipenser baeri) // Aquatic Living Resources. 1998. Vol. 11. P. 111-118. 
184. Wong Y. L., Binkowski F. P. Effect of temperatyre on early development of white and lake sturgeon Acipenser transmontanus and A. fulvescens // Environmental Biology of Fishes. 1985. Vol. 14. P. 43-50.

185. Xie D., Tiang Y., Chen D. Study of domestication of the shanjiang sturgeon in pond // Intern. symp. on sturgeons and paddlefishes : proceedings. Chonqing, China, 1992. P. 6-7.

186. Zhu Y., Wei Q., Yang D. Large-scale cultivation of fingerlings of the Chinese Sturgeon (Acipenser sinensis) for re-stocking: a description of current technology // Journal of Applied Ichthyology. 2006. Vol. 22. P. 238-243.

187. Zhuang P., Yi J. Sturgeon and paddlefish aquaculture in China // Journal of Applied Ichthyology. 1999. Vol. 15. P. 334.

\section{REFERENCES}

1. Bronzi, P., Rosenthal, H., Arlati, G., \& Williot, P. (1999). A brief overview on the status and prospects of sturgeon farming in Western and Central Europe. Journal of Applied Ichthyology, 15, 224-227.

2. Abdolhay, H., Tahori, H. B. (1997). Fingerling production and stock enhancement of Sturgeon in South of the Caspian Sea. 3rd International symposium on Sturgeon, Piacenza, Italy, July 8-1: booklet of abstracts, 298.

3. Hung, S. O., Fynn-Aikins, F. K., Lutes, P. B., \& Xu, R. (1989). Ability of juvenile white stutgeon (Acipenser transmontanus) to utilize different carbohydrate sources. The Journal of Nutrition, 119, 727-733.

4. Amaoka, K., \& Nakaya, K. (1975). First record of Caluga Sturgeon (Huso dauricus), from Japan. Japanese Journal of Ichthyology, 22, 164-166.

5. Arlaiti, G., Bronzi, P., Colombo, L., \& Giovannini, G. (1998). Induced breeding of the Italian sturgeon (Acipenser naccarii) raised in captivity. Riviy Italy Acquacoltore, 23, 94-96.

6. Arlati, G., Grassi, A., \& Granata, A. (1997). Restocking Lombardian region rivers with the anadromous Adriatic sturgeon (Acipenser naccarii). 3rd International symposium on Sturgeon, Piacenza, Italy, July 8-1: booklet of abstracts, 47.

7. Williot P., Rouault T., Pelard M., Mercier D., \& Jacobs L. (2009). Artificial reproduction and larval rearing of captive endangered Atlantic sturgeon (Acipenser sturio). Endangered Species Research, 6, 251-257.

8. Sun, D. J., Qu, Q. Z., Wu, W. H., Ma, G. J., Qiu, L. Q. Xia, Y. T., \& Tan, J. C. (2003). Artificial spawning and aquaculture of Amur sturgeon. Beijing, China: China Ocean press, 96.

9. Boglione, C., Bronzi, P., Cataldi, E., Serra, S., Gagliardi, F., \& Cataudella, S. (1999). Aspects of early development in the Adriatic sturgeon (Asipenser naccarii). Journal of Applied Ichthyology, 15, 207-213.

10. Auer, N. A. (1994). Effects, of change, in operation of a small hydmekctrie facility on spawning characteristics of lake sturgeon. Lake and Reservoir Management, 9, 52-53.

11. Bacalbasa-Dobrovici, N. (1993). Saving of Romanian sturgeon needs a consequent strategy and tactics. Analele Atiintifice ale Institutului-Delta Dunarii. 221-226.

12. Bachmani, M., Kazemi R., \& Donskaya P. (2001). A comparative study of some hematological features in young reared sturgeons (Acipenser persicus and Huso huso). Fish Physiology and Biochemistry, 24, 135-140.

13. Badino, G., Maiorana, G., \& Montorio, L. (1997). Growth juveniles of Italian sturgeon (Acipenser naccarii Bonoparte). 3rd International symposium on Sturgeon, Piacenza, Italy, July 8-1: booklet of abstracts, 74-77. 
14. Bain, M. (1997). Atlantic and shortnose sturgeons of the Hudson River: common and divergent life history attributes. Environmental Biology of Fishes, 48, 347-358.

15. Beamesderfer, R. C. P., Rien, T. A., \& Nigro A. A. (1995). Differences in the dynamics and potential production of impounded and unimpounded white sturgeon populations in the Lower Columbia River. Transactios of the American Fisheries Society, 124, 857-872.

16. Beamesderfer, R. C. P., \& Farr, R. A. (1994). Alternatives for the protection and restoration of sturgeos and their habitat. Proceedings of the International Conference on Sturgeon Biodiversity and Conservation. New York.

17. Beamish, W. E., \& William, H. (1996). Growth strategy of juvenuile lake sturgeon (Acipenser fulvescens) in a northern river. Canadian Journal of Fisheries and Aquatic Sciences, 53, 481-489.

18. Beamih, W. E., Findeis, E. K., \& Grande, L. An overview of Acipenseriformes. Environmental Biology of Fishes, 48, 25-71.

19. Bean-Knudsen, E. D., Uhazy, L. S., \& Wagner, J. E. (1987). Cranial chondrosarcoma in a paddlefish (Polyodon spathula Walbaum). Journal of Fish Diseases, 10, 363-369.

20. Zyuang, P., Keb, F., Wey, Q., He, X., \& Cen J. (1996). Biology and life history of Dabry sturgeon (Acipenser debryanus). Proseeding of the Internat. conf. on sturgeon biodiversity and conservation, 4, 286-292.

21. Wei, Q., Ke, F., Zhang, J., Zhuang, J., Luo, J., Zhou, R., \& Yang V. (1997). Biology, fisheries, and conservation of sturgeons and paddlefish in China. Environmental Biology of Fishes, 48, 241-255.

22. Williot, P., Rochard, E., Desse-Berset, N., Kirschbaum, F., \& Gessner, J. (Eds.) (2011). Biology and conservation of the European Sturgeon Acipenser sturio L. 1758: The Reunion of the European and Atlantic Sturgeons. Springer Science \& Business Media.

23. Birstein, V. J., Beamish, W. E. (1997). Leo Semenovich Berg and the biology of Acipenseriformes: a dedication. Environmental Biology of Fishes, 48, 15-22.

24. Birstein, V. J. (1996). Sturgeons may soon disappear from the Caspian Sea. Russian Conservatin News Spring, 7, 15-16.

25. Birstein, V. J., \& Beamish, W. E. (1995). Endangered Status. The Sturgeon Quarterly, 3, 1-12.

26. Birstein, V. J. (1993). Sturgeons and Paddlefishes: Threatened fishes in need of conservation. Conservation Biology, 7, 773-787.

27. Bramick, U. (1992). Sturgeon in the pond-fish farm. Fischer und teichwirt, 43, 7-9.

28. Bruch, R. M., Miller, G., \& Hansen, M. G. (2006). Fecundity of Lake Sturgeon (Acipenser fulvescens, Rafinisque) in Lake Winnebago, Wisconsin, USA. Journal of Applied Ichthyology, 22, 116-118.

29. Bruch, R. M. (1999). Management of lake sturgeon on the Winnebago System long term impacts of harvest and regulations on population structure. Journal of Applied Ichthyology, 15, 142-152.

30. Bruch, R. M. (1998). Management and trade of Lake Sturgeon in North America. Symposium on the Harvest, Trade and Conservation of North American Paddlefish and Sturgeon: Chattanooga, Tennesee. 96.

31. Brundaqe, H. M., \& Meadows, R. E. (1982). Occurrence of the endangered Shortose sturgeon (Acipenser brevirostrum) in the Delaware River estuary. Estuaries, 5, 203-208. 
32. Buddington, R. K. (1985). Digestive secretions of lake sturgeon (Acipenser fulvescens), during early development. Journal of Fish Biology, 26, 715-723.

33. Burggren, W. W. (1978). Gill ventilation in the sturgeon, unusal adaptations for bottom dwelling. Respiratory Physiology \& Neurobiology, 34, 153-170.

34. Agnisola, C., McKenzie, D. J., Pellegrino, D., Bronzi, P., Tota, B., \& Taylor, E. W. (1999). Cardiovascular responses to hypoxia in the Adriatic sturgeon (Acipenser naccarii). Journal of Applied Ichthyology, 15, 6-7.

35. Cech, J. J., Mitchill, S. J., \& Wragg, T. E. (1984). Comparative growth of juvenile with sturgeon and stripped bass: effects of temperature and hipoxia. Estuaries, 7, 12-18.

36. Celikkale, M. S., Memis, D., \& Ercan, E. (2005). Growth performance of juvenile Russian sturgeon (Acipenser gueldenstaedti Brandt \& Ratzenburg, 1983) at two stocking densities in net cages. Journal of Applied ichthyology, 21, 14-18.

37. Ceskleba, D. G. S., \& Thuemler, T. F. (1985). Artificial spawning and rearing of Lake Sturgeon (Acipenser fulvescens) in Wild Rose Fish Hatchery, Wisconsin, 1982-1983. Environmental Biology of Fishes, 14, 79-85.

38. Chang, J. (1999). Immersion marking of larval Chinese sturgeon (Acipenser sinensis) with alizarin. Journal of Applied Ichthyology, 15, 238-243.

39. Chapman, F. A., Van Eenennaam, J. R., \& Doroshov, S. I. (1996). The reproductive condition of white sturgeon (Acipenser transmontanus) in San Francisco Bay, California. Fishery Bulletin, 94, 628-634.

40. Charlon, N., \& Bergot, P. (1991). Artifical feeding of Siberian stergeon. Acipenser Actes ler Collog international Esturgeon, Bordeaux, 3-6 oct., 1991, 405-415.

41. Collins, M. R., Smith, T. J., \& Heyward, L. D. (1994). Effectiveness of six methods for marking juvenile shortnose sturgeons. The Progressive Fish-Cufturist, 56, 250-254.

42. Collins, M. R., Smith, T. I. J., Ware, K., \& Quattro, J. (1999). Culture and stock enhancement of shornose sturgeon and Atlantic sturgeons. Bull. Nation. Res. Inst. Aquacult, 101-108.

43. Czeczuga, B. (1982). Content of carotenoids in eggs utilized in the form of caviar. Folia Histochemica Et Cytochemica, 20, 63-68.

44. Czeczuga, B. (1971). Carotenoids in the eggs of Acipenser ruthenus L. (Acipenseridae) from the Danube. Hidrobiologia, 39, 9-16.

45. Dabrowski, K., Kausik, S. J., \& Fauconean B. (1985). Rearinng of sturgeon (Acipenser baeri Brandt) larvae. Aquaculture, 47, 17-29.

46. Dadswell, M. J., \& Potte, R. A. (1983). Locomotor behaviour and preliminary assesmrat of critical swimming speeds for juvenil sturgeon Acipenser brevirostrum and Acipenser oxyrhynchus. Abstr. 113-th Ann meeting of the American Fisheries Society, 105-106.

47. Dadswell, M. J. (1979). Biology and population characteristics of the shortnose sturgeon (Acipenser brevirostrum LeSeur 1818), in the Saint John river estuary, New-Brunswick, Canada. Canadian Journal of Zoology, 57, 2186-2210.

48. Debus, L. (2002). When the American sea sturgeon swam east (A colder Baltic Sea greeted this fish from across the Atlantic Ocean in the Middle Ages). Nature, 419, 447-448.

49. Debus, L., \& Groger, J. (2000). Morphometry comparison of Acipenser sturio L. populations based on mixed estimation and morphometric measurements. Archive of Fishery and Marine Research, 48, 175-193.

50. De Melenaer, T., \& Raymakers, C. (1996). Sturgeons of the Caspian Sea and the international trade in caviar. TRAFFJC International, 71. 
51. Mogxim, M., Vajhi, A. R., Veshkini, A., \& Masoudifard, M. (2002). Determination of sex and maturity in sturgeon (Acipenser stellatus) by using ultrasonography. Journal of Applied Ichthyology, 18, 325-328.

52. Sadowski, J., Trzebiatowski, R., Odebralska, D., \& Wielopolska M. (2000). Determination of optimal feed rations for Siberian sturgeon (Asipenser baeri) kept in cooling water. Falia Univ. Agrie. Stetin, 214, 193-199.

53. Bath, D., O'Connor, J., Alber, J., \& Arvidson, L. (1981). Developmentand identification of larval Atlantic sturgeon (Acipenser oxyrhynchus) and shortnose sturgeon (A. brevirostrum) from the Hudson River Estuary, New York. Copeia, 3, 711-717.

54. Zhuang, P., Zhuang, L., Zhuang, T., Zhuang, Z., Liu, L., Zhuang, J., Ge, F., Yi. J., \& Liu, W. (1998). Domestication and biology of Amur sturgeon (Acipenser schrenckii) in central China: I. Growth of young-of-the-year. Freshwater Fisheries, 28, 6-9.

55. Doroshov, S. I., Moberg, G. P., \& Van Eenennaam, J. P. (1997). Observations on the reproductive cycle of cultured white sturgeon (Acipenser transmontanus). Environmental Biology of Fishes, 48, 265-278.

56. Doroshov, S. I., \& Lutes, P. B. (1984). Preliminaty data on the induction of ovulation in white sturgeon (Acipenser transmontanus Richardson). Aquaculture, 30, 221-227.

57. De Vore, I. D., James, B. W., Traeey, C. A., \& Hale, D. H. (1995). Dynamics and potential production of White Sturgeon in the unimpounded lower Columbia River. Transactions of the American Fisheries Society, 124, 845-856.

58. Ebrahimi, E. (2006). Determination of the best time to transfer Beluga (Huso huso) juveniles from natural to commercial diets. Journal of Applied Ichthyology, 22, 274-277.

59. Ebrahimi, E., \& Zare, P. (2006). Growth and survival of Beluga (Huso huso) and Persian sturgeon (Acipenser persicus) fingerlings fed by live food and artificial diet. Journal of Applied Ichthyology, 22, 321-324.

60. Echols, J. E. (1995). Fraser River Action Plan Fishery Management Group. Review of Fraser River White Sturgeon (Acipenser transmontans). Department of Fisheries and Oceans, Vancover, B. C. 33.

61. Mc Kenzie, D. J., Piraccini, G., Steffensen, G. F., Bolis, C. L., Bronzi, P., \& Taylor, E. W. (1995). Effects of diet on spontaneous locomotor activity and oxygen consumption in Adriatic sturgeon (Acipencer naccarii). Fish Physiology \& Biochemistry, 14, 341-355.

62. Elvira, B., \& Almodovar, A. (1993). Notice about the survival of sturgeon (Acipencer sturio L., 1758) in the Guadalquivir estuary (S. W. Spain). Archiv fur Hydrobiologie, 129, 253-255.

63. Fahim, H. R. (1991). Breeding and mass production of sturgeons. Zetoun magazine, 103, 174-183.

64. Fange, R. (1986). Lymphoid organs in sturgeons (Acipenseridae). Veterinary Immunology and Immunopathology, 12, 153-161.

65. Fashtomi, H. R. P., \& Mohseni, M. (2006). Survival and growth of larval and juvenile Persian sturgeon (Acipenser persicus) using formulated diets and live food. Journal of Applied Ichthyology, 22, 303-306.

66. Le Menn, F., Pelissero-Benettou, C., Williot, P., \& Cuisset-Davail, B. (1999). Female Siberian sturgeon (Acipenser baeri): an interesting model for reproductive physiology studies in fish. Journal of Applied Ictiology, 15, 315-316. 
67. Gessner, J., Hochleithner, M. (1999). The sturgeons and Paddlefishes (Acipenseriformes) of the World. Biology and Aguaculture. Austria, 165.

68. Gessner, J., Hochleithner, M., Anders, E., Arndt, G. M., Spratte, S., \& Rosenthal, H. (1997). European-wide coordination trial for programmes to save the common sturgeon Acipenser sturio L.). 3rd International symposium on Sturgeon, Piacenza, Italy, July 8-1: booklet of abstracts, 28.

69. Gilbert, C. R. (1992). Atlantic sturgeon. Vol. II: Fishes. Gainesville: University Press of Florida, 5-8.

70. Gisbert, E., Williot, P., \& Castello-Orvay, F. (2000). Influence of egg size of sibirian sturgeon (Acipenser baeri) under small scale hatchery conditions. Aquaculture, 183, 83-94.

71. Gisbert, E., \& Williot, P. (1998). Larval behaviour and effect of the timing of initial feeding on growth and survival of Siberian sturgeon larvae under small scale hatchery production. Aquaculture, 52, 54-62.

72. Gisbert, E., \& Williot, P. (1997). Behavioural reactions of Siberian sturgeon (Acipenser baeri, Brandt) to different modifications of environmental rearing conditions during early ontogeny. Journal of Fish Biology, 50, 100-138.

73. Omoto, N., Maehayashi, M., Hara, A., Adachi, S., \& Yamauchi K. (2004). Gonadal maturity of wild sturgeons Huso dauricus, Acipenser mikadoi and A. schrenckii caught near Hokkaido, Japan. Enviromental Biology of Fishes, 70, 381-391.

74. Grandi, M., \& Chicca, D. (2004). Early development of the pituitary gland in Acipenser naccarii (Chondrostei, Acipenseriformes): an immunocytochemical study. Anatomy and Embryology, 208, 310-321.

75. Groger, J., \& Debus, L. (2000). Morphometric comparison of Acipenser sturio L. populations based on mixed estimation and morphometric measurements. Archive of Fishery Marine Research, 48, 175-193.

76. Giovanni, G., Colombo, L., Bronzi, P., \& Arlati, G. (1989). Growth of hatcheryproduced juveniles of Italian sturgeon (Acipenser nacarii Bonaporte) reared intensively in fresh water. Acipenser. Prem. Col-Intern. L'Esturg., Bordeaux. Cemagref, 401-415.

77. Hall, J. W., Smith, T. J., \& Lamprecht, S. D. (1991). Movements and habitats of shortnose sturgeon (Acipencer brevirostrum) in the Savannah River. Copeia, 3, 695-702.

78. Hung, S. O., Storebakken, T., Cui, Y., Tian, L., \& Einen, O. (1997). High-energy diets for white sturgeon (Acipenser transmontanus Richardson). Aquaculture Nutrition, 3, 281-286.

79. Hjul, P. (1996). French farms now ready with the Fish of Kings. Fish Farming Internaional, 23, 32-33.

80. Hochleithner, M., \& Gessner, J. (2001). The sturgeons and paddlefishes of the world biology and aquaculture. AquaTech Publications. Austria, Kitzbuehl, 207.

81. Honma, Y., \& Itano, H. (1994). A record of Great Siberian Sturgeon (Huso dauricus) off Niigata, Sea of Japan. Japanese Journal of Ichthyology, 31, 317-321.

82. Parauka, F. M., Troxel, W. J., Chapman, F. A., \& Mc Bay, L. G. (1991). Hormoneinduced ovulation and artificial spawning of Gulf of Mexico sturgeon (Acipenser oxyrhynchus desotoi). Progress. Fish Culturist, 53, 113-117.

83. Horvath, L., Peteri, A., \& Kouril, J. (1986). Successful sterlet (Acipenser ruthenus L.), propagation with synthetic LH-RH hormone. Aquaculture and fish management, 17, 113-116.

84. Hossain, A. (1997). Fingerling prodaction and stock enhancement of sturgeon in south of Caspian sea. 3rd International symposium on Sturgeon, Piacenza, Italy, 
July 8-1: booklet of abstracts, 21-23.

85. Houston, J. J. P. (1988). Status of the Green Sturgeon (Acipenser medirosris) in Canada. The Canadian Field Naturalist, 102, 286-290.

86. Houston, J. J. P. (1987). Status of the lake sturgeon (Acipenser fulvescens) in Canada. The Canadian Field Naturalist, 102, 171-185.

87. Hung, S. O., Conte, F., \& Lutes, P. B. (1995). Optimal retion of white sturgeon at commercial rearing. Journal of Applied Aquaculture, 1, 45-51.

88. Hung, S. O., \& Fynn-Aikins, F. K. (1993). Carbohydrate utilization and its impact on some metabolic and histological parameters in wait sturgeon. Fish nutrition in practice. IV intern. symps. on fish nutrition and feeding. Paris: INRA, 15.

89. Rzemieniecki, A., Domagalla, J., Glogowskl, J., Cierezko, A., Trebiatowski, R., Kourjil, J., Hamackova, J., \& Babiac I. (2004). Induced spermiation in 3-year-old sterlet, Acipenser rutnenus L. Aquaculture Research, 35, 144-151.

90. Garsia-Gallego, M., Sanz, A., Domezain, A., \& De la Higuera, M. (1997). Influences on tissue lipid quality of the sturgeon (Asipenser naccari) from intensive culture. 3rd International symposium on Sturgeon, Piacenza, Italy, July 8-1: booklet of abstracts, 80-81.

91. Di Marco, P., Mc Kenzie, D. J., Mandich, A., Bronzi, P., Cataldi, E., \& Cataudella, S. (1999). Influence of sampling conditions on blood chemistry values of Adriatic sturgeon (Acipenser naccarii Bonaparte, 1836). Journal of Applied Ichthyology, $15,73$.

92. Jiang, L.-F. (1997). Effects of ecologic environmental pollution on Chinese sturgeon (Acipenser sinensis). 3rd International symposium on Sturgeon, Piacenza, Italy, July 8-1: booklet of abstracts, 207-208.

93. Jose, L. O., Jose, M. I., \& Domezain, A. (2003). Corpuscle of the sturgeon kidney: an ultrastructural, chemical dissection, and lectin-binding study. The Anatomical Record, 2, 563-573.

94. Keenlyne, K. D., \& Maxwell, S. J. (1993). Length conversions and length-weight relations for pallid sturgeon. North American Journal of Fisheries Management, 13, 395-397.

95. Kempinger, J. J. (1988). Spawning and early life history of lake sturgeon in the Lake Winnebago system, Wisconsin. American Fisheries Society Symposium, 5, $110-122$

96. Kempinger, J. J. (1996). Habitat, growth and food of Young Lake Sturgeon in the Lake Winnebago System, Wisconsin. North American Journal of Fisheries Management, 16, 102-114.

97. Kennedy, A. J., Sutton, T. M., \& Fisher, B. E. (2006). Reproductive biology of female shovelnose sturgeon in the upper Wabash River, Indiana. Journal of Applied Ichthyology, 22, 177-182.

98. Kieffer, M., Kinard, B. (1993). Annual movements of shortnose and Atlantic sturgeons in the Merrimack River, Massachusetts. Transactions of the American Fisheries Society, 122, 1088-1103.

99. Kime, D. E., Lambert, J. G., \& Bukovskaya, O. V. (1996). Steroid synthesis by gonads of the Russian sturgeon (Acipenser gueldenstaedti). Annual Endocrinology, 57, 4-22.

100. Kohlhores, D. W. (1976). Sturgeon spawning in the Sacramento river in 1973, as determined by distribution of larvae. Californian Fish and Game, 62, 80-86.

101. Kurfurst, J., Kerber, P., \& Kakous, L. (2000). Growth of Siberian sturgeon (Acipenser Baerii) in the Czech Republics conditions. Czech Journal of Animal 
Sciences, 45, 545-552.

102. Linares-Casenave, J., Van Eenennaam, J. P., \& Doroshev, S. I. (2002). Ultrastructural and histological observations on temperature induced follicular ovarian in the white sturgeon. Journal of Applied Ichthyology, 18, 382-390.

103. Logan, S. H., Johnston, W. E., \& Doroshov, S. I. (1995). Economics of joint production of sturgeon (Acipenser transmontanus Richardson) and roe for caviar. Aquaculture, 12, 299-316.

104. Loy, A., Bronsi, P., \& Molteni, S. (1999). Geometric morphomertric in the characterization of the cranial growth pattern of Adriatic sturgeon (Acipenser naccarii). Journal of Applied Ichthyology, 15, 1-50.

105.Lutes, P. B. (1985). Oocyte maturation in white sturgeon (Acipenser transmontanus): some mechanisms and applications. Environmental Biology of Fishes, 14, 87-92.

106. Brun, R., Rochard, E., Torre, M., \& Elie, P. (1997). Marking of sturgeon Acipenser sturio L. alevins dedtined for restocking. 3rd International symposium on Sturgeon, Piacenza, Italy, July 8-1: booklet of abstracts, 4-7.

107. May den, R. L., Kuhajda, B. R. (1996). Systematics, taxonomy, and conservation status of the endangered Alabama sturgeon (Scaphirhynchus suttkusi William and Clemmer (Actinopteiygii, Acipenseridae)). Copeia, 2, 241-275.

108. Mc Cade, G. T., Gejrge, T., \& Tracy, C. A. (1994). Spawning and early life history of white stugeon (Acipenser transmontanus) in the lower Columbia river. Fisheries Bulletin, 92, 760-772.

109. Mc Cade, G. T., Emmett, R. L., \& Hinton, S. A. (1993). Feeding ecology of juvenile white sturgeon (Acipenser transmontanus) in lower Columbia River. Northwest Science, 67, 170-180.

110. Mc Cade, G. T., Pried, S., \& Towt, A. (1977). Daili movements of short nose sturgeon (Acipenser brevirostrum) in a Maine estuary. Copeia, 1, 149-157.

111. Mc Enroe, M., \& Cech, J. J. (1985). Osmoregulation in juvenile and adult White sturgeon (Acipenser transmontanus). Environmental Biology of Fishes, 14, 23-30.

112. Meulenaer, T., \& Raymaker, C. (1996). Sturgeons of the Caspian Sea and the international trade in caviar. TRAFFJC International. 71.

113. Mohler, J. W. (1996). Feeding trials with juvenile atlantic sturgeons propagated from wild broodstock. Progr. Fish.-Cult., 58, 173-177.

114. Moos, R. E. (1978). Movement and reproduction of shovenose sturgeon (Scaphirynchus platoiynehus) in the Missouri River, South Dakota. Ph. Dissertation, Vermillion. University of South Dakota, 216.

115. Mims, S. D. (1995). Will the Chinese Paddlefish Survive? Sturgeon Quarterly, 3, $1-12$.

116. Keenlyne, K. D., Henry, C. J., Tews, A., \& Clancy, P. (1994). Morphometric comparisons of upper Missouri River sturgeons. Transactions of the American Fisheries Society, 123, 779-785.

117. Nagy, S. (1987). The food of sterlet (Acipenser ruthenus L.) in the czechoslovarungarian section of the Danube. Folia zoologica, 281-287.

118. National Paddlefish and Sturgeon Steering Committee (NPSSC). (1993). Framework for the management and conservation of paddlefish and sturgeon species in the United States.

119. Navodaru, I., Stara, M., \& Banks, R. (1999). Management of sturgeon stocks of the lower Danube River system. The Delta's: State-of-art protection and management: conference proceedings, Tulcea, Romania, 26-31 July, 229-237. 
120. Ludwig, A., Congiu, L., Pitra, C., Fickel, J., Gessner, J., Fontana, F., Patarnello, T., $\&$ Zane, L. (2003). Nonconcordant evolutionary history of maternal and paternal lineages in Adriatic sturgeon. Molecular Ecology Resources, 12, 3253-3264.

121. Binkowski, F. P., \& Doroshov, S. I. (Eds.) (1985). North American Sturgeons: Biology and Aquaculture Potential. The Netherlands, Dordrecht: Dr. W. Junk Publishers.

122. North, J. A., Beamesderfer, R. C., \& Rien, T. A. (1993). Distribution and movements of white sturgeon in three lower Columbia River reservoirs. Northwest Science, 67, 105-111.

123. Cuisset, B., Fostier, A., Williot, P., Benneteu-Pelissero, C., \& Le Menn, F. (1995). Occurence and in vitro biosynthesis of 11-ketotestosterone in Siberian sturgeon, (Acipenser baeri Brandt) maturing females. Fish Physiology \& Biochemystry, 14, 313-322.

124. Smith, T. J., Mc Cord, J. W., Collins, M. R., \& Post, W. C. (2002). Occurrence of stocked shortnose sturgeon (Acipenser brevirostrum) in non-target rivers. Journal of Applied Ichthyology, 18, 470-474.

125.Zhuang, P., Kunard, B., Zhuang, L., Zhuang, T., Zhuang, Z., \& Li, D. (2002). Overview of biology and aquaculture Amur sturgeon (Asipenser schrencrii) in China. Journal of Applied Ichthyology, 18, 659-664.

126. Paaver, T. A. (1996). Common or Atlantic sturgeon (Acipenser sturio) was cought in the Estonian waters of the Baltic sea. The Sturgeon Quarterly, 4, 1-7.

127. Parauka, F. M. (1993). Guidelines for artificially spawning Gulf sturgeon. Florida, USA.

128. Pecheanu, C. T., Vasile, M., \& Patriche, N. (1993). Some results of artificial propagation of Acipenser stellatus at the Brates hathery, Galati. Ananele Atiintifice ale Institutului-Delta Dunarii, 169-170.

129. Ping, Z., \& Jifang, Y. (1997). Sturgeon and paddlefish aquaculture in China. 3rd International symposium on Sturgeon, Piacenza, Italy, July 8-1: booklet of abstracts, 399.

130. Poliakova, L., Artaly, G., \& Giovannini, J. (2001). The use of the synthetic hormone LH-RH (d-ala6) for reproductive control of wild caught and captivity raised sturgeons. Proceedings of the 4th International Symposium on sturgeon. Oshkosh, Wisconsin, USA, 160.

131. Parandavar, H., Kazemi, R., Pourali, H. R., Vahabi, Y., \& Pourkazemi, M. (2006). Potential for egg extraction from female sturgeon spawners through key-hole surgery. Journal of Applied Ichthyology, 22, 287-290.

132. Potts, W. T. W., \& Rudy, P. P. (1972). Aspects of osmotic and ionic regulation in the sturgeon. Journal of Experimental Biology, 56, 703-715.

133. Priegel, G. R. (1973). Lake sturgeon management on the Menominee River. Wic. Dep. Nat. Resour., Technical bulletin, 67, 20.

134. Prokes, M., Barus, V., \& Penaz, M. (1995). Morphometrical analysis of 0+ juvenile giant sturgeon (Huso huso) rearing in the Czech republic for first time. Folia zoological, 44, 269-278.

135. Clementi, M. E., Cataldi, E., Capo, C., Petruzzelli, R., Tellone, E., \& Giardina, B. (1999). Purification and characterization of the hemoglobin components of Adriatic sturgeon (Acipenser naccarii) blood. Journal of Applied Ichthyology, 15, 7-8.

136. Rasuli, M. (1991). Sturgeons, suitable species for breeding and rearing. Abjiyan magazine, 16, 70-72. 
137. Raymakers, C. (2006). CITES, the Convention on International Trade in Endangered Species of Wild Fauna and Flora: its role in the conservation of Acipenseriformes. Journal of Applied Ichthyology, 22, 53-65.

138. Raymakers, C., \& Hoover, C. (2002). Acipenseriformes: CITES impementation from Range States to consumer countries. Journal of Applied Ichthyology, 18, 629638.

139. Rieman, B. E., \& Beamesderfer, R. C. (1990). White sturgeon in lower Columbia River: Is the stock overexploited? North American Journal of Fisheries Management, 10, 388-396.

140. Tranah, G. J., Kincaid, H. L., Krueger, C. C., Campton, D.E., \& May, B. (2001). Reproductive isolation in sympatric populations of pallid and shovelnose sturgeon. North American Journal of Fisheries Management, 21, 367-373.

141. Ronyal, A., Csengeri, I., \& Varadi, L. (2002). Partial substitution of animal protein with full-fat soybean meal and amino acid supplement in the diet of Siberian sturgeon (Asipenser baeri). Journal of Applied Ichthyology, 19, 682-684.

142. Ronyal, A. (1998). Effect of food ration and water temperature on growth of juvenile Siberian sturgeon (Acipenser baerii). Journal of Applied Ichthyology, 15, 344-345.

143. Rossiter, A., Noakes, D. L., \& Beamish, E. W. (1995). Validation of the Age Estimation for the Lake Sturgeon. Transactions of the American Fisheries Society, 124, 777-781.

144. Roussow, G. (1957). Some considerations concerning sturgeon spawning periodicity. Journal of fisheries research Board of Canada, 14, 553-572.

145. Sangalang, G. B., Weisbart, M., \& Idler, D. R. (1971). Steroids of a chondrostean: corticosteroids and testosterone in the plasma of the american atlantic sturgeon, (Acipenser oxyrhynchus Mitchill). Journal of Endocrinology, 50, 413-421.

146. Sheibani, M. T. (2002). A histological study on some organ tissues involved in the immune system of Acipenser persicus. Agriculture and Natural Resources: Abstracts of The 3rd International Iran and Russia Conference. Moscow: MTAA, 159.

147. Smith, T. J., \& Collins, M. R. (1996). Shortnose sturgeon stocking success in Savannah River. Proc. Ann. Conf. Southeast Assoc. Fish and Wildl. Agencies 50, 112-121.

148. Smith, T. J. (1990). Culture of North American sturgeons for fishery enhancement. PNOAA Technical Reptort NMFS, 85, 19-27.

149. Smith, T. J., Oldland, W., \& Jenkins, W. E. (1988). Development of nursery systems for short-tnose sturgeon (Acipenser brevirostrum). Proc. Ann. Conf. Southeast. Ass. Fish \& Wildlife Agencies, 140, 143-151.

150. Smith, T. J., Dingley, E. K., \& Marchette, D. E. (1980). Induced spawning and culture of the Atlantic sturgeon (Acipenser oxyrhynchus). Progres. Fish-Culturist, 42, 147-151.

151. Cataldi, E., Barzaghi, C., Di Marco, P., Boglionel, C., Dini, L., Mc Kenzie D. J., Bronzi, P., \& Cataudella S. (1999). Some aspects of osmotic and ionic regulation in Adriatic sturgeon: Ontogenesis of salinity tolerans. Journal of Applied ichthyology, 15, 61-65.

152. Smith, T. J., Dingley, E. K., Lindsey, R. D., Van Sant, S. B., Smiley, R. A., \& Stokes, A. D. (1985). Spawning and culture of shortnose sturgeon (Acipenser brevirostrum). World Mariculture Society, 16, 104-113. 
153. Palmegiano, G. B., Agradi, E., Fomeris, G., Gai, F., Gasco, L., Rigamonti, E., Sicuro, B., \& Zoccarato, I. (2005). Spirulina as a nutrient source in diets for growing sturgeon (Acipenser baeri). Aquaculture Research, 36, 1-88.

154. Wei, Q., He, J., Yang, D., Zheng, W., \& Li, L. (2004). Status of sturgeon aquaculture and sturgeon trade in China: a review based on two recent nationwide surveys. Journal of Applied Ichthyology, 20, 321-332.

155. Bronzi, P., Arlati, G., Rosenthal, H., \& Williot, P. (1997). Status and prospects of sturgeon farming in Western Europe. 3rd International symposium on Sturgeon, Piacenza, Italy, July 8-1: booklet of abstracts, 121-123.

156. Steffens, W., Jahnichen, H., \& Fredrich, F. (1990). Possibilities of sturgeon culture in Central Europe. Aquaculture, 89, 101-117.

157. Stevens, D. E. (1970). Distribution of sturgeon larvae in the Sacramento San Joaguin river system. Californian Fish and Game, 56, 80-86.

158. Smith, T. J., Collins, M. R., Post, W. C., \& Mc Cord J. W. (2002). Stock enhancement of shornose sturgeon: a case study. Transaction of American Fisheries Society, 28, 31-44.

159. Statescu, M., Pecheanu, C., Trofimov, A., \& Vasile, M. (1993). Studies of morphophenotypes of stellate sturgeon (Acipenser stellatus) from the Brates farm-Galati. Analele Atiinfice ale Institutului-Delta Dunarii, 185-188.

160. Birstein, V. J., Waldman, J. R., \& Bemis, W. E. (Eds.) (2002). Sturgeon biodiversity and conservation. London: Kluwer Academic Publishers.

161. Bronzi, P., Arlati, G., Cataudella, S., \& Rossi, R. (1996). Sturgeon distribution in Italy. Proceeding of the International Conference on Sturgeon Biodiversity and Conservation. New York, 32-36.

162. Dadswell, M. J., Taubert, B. D., Squiers, T. S., Marchette, D., \& Buckley, J. (1984). Synopsis of biological data on shortnose sturgeon (Acipenser brevirostrum, LeSueur 1818). FAO Fisheries Synopsis.

163. Taylor, S. (1996). The historical development of the caviar trade and industry. Sturgeon stocks and caviar trade: German workshop. Bonn, 121-134.

164.Zhao, L.-W., Qiu, L.ing-Q., Liu, H.-B., Yang, Y.-H., \& Ye, J.-D. (2004).The culture of Amur sturgeon (Acipenser schrenki) at different feed rates. Journal Fisheries Sciences of China, 11, 375-378.

165. Sun, D., Qu, Q., Wu, W., \& Ma, G. (2002). The resource situation of sturgeons in the Heilongjiang River. Technical compendium to the proceedings of 4th international symposium on sturgeon. Sea Grant University of Wisconsin, 1-6.

166. La Patra, S. E., Groff, J. M., Patterson, T. L., Shewmaker, W. D., Casten, M., Siple, J., \& Hauck, A. K. (1996). The effect of sturgeon density on manifestation of white sturgeon iridovirus disease. Journal of Applied Aquaculture, 6, 51-58.

167. Williot, P., Nonnotte, G., Vizziano-Cantonnet, D., \& Chebanov, M. (Eds.) (2018). The Siberian Sturgeon (Acipenser baerii, Brandt, 1869). Springer International Publishing.

168. Thuemler, T. F. (1996). Lake Sturgeon management in the Menominee River, a Wisconsim-Michigan Boundary Water. Proceeding of the International Conference on Sturgeon Biodiversity and Conservation. New York, 82-93.

169. Tortonese, E. (1989). Acipenser naccarii Bonaparte 1836. Holcik J. (ed). The Freshwater Fishes of Europe. Vol. 1/2: General Introduction of Fishes. Acipenseriformes. Wiesbaden: AULA-Verlag, 285-293. 
170. Vizziano, D., Barrios, F., Astigarraga, I., Breton, B., \& Williot, P. (2015). Unusual conditions for Siberian sturgeon (Acipenser baerii Brandt) spawning. Journal of Applied Ichthyology, 22, 325-330.

171. Vaisman A., \& Raymakers C. (2001). The Status of Sturgeon resources in Russia. TRAFFIC Bulletin, 19, 33-44.

172. Vasile, M., Pecheanu, C., \& Patriche, N. (1993). Some results of superintensive raising techno-logy of Acipenser stellatus. Analele Atiintifice ale Institutului-Delta Dunarii, 385-386.

173. Varadi, L., \& Ronyai, A. (1999). The history, current research and future potential of sturgeon culture in Hungary. Journal of Applied Ichthyology, 15, 329-330.

174. Vecsei, P., Charette, R., \& Hochleithner, M. (2004). Guide to the Identification of Sturgeon and Paddlefish Species Controlled under the Convention on International Trade in Endangered Species of Wild Fauna and Flora. Ottava: CITES, 30-33.

175. Waldman, J. R., \& Wirgin, I. (1998). Status and restoration options for Atlantic sturgeon in North America. Ecology and Conservation Biology, 12, 631-638.

176. Wang, Y. L., \& Chang, J. L. (2006). Status and conservation of sturgeons in Amur River, China: a review based on surveya sinse the year 2000. Journal of Applied Ichthyology, 22, 44-52.

177. Wang, Y. L., Buddington, R. K., \& Doroshov, S. I. (1987). Influence of temperature on yolk utilization by the white sturgeon (Acipenser transmontanus). Journal of Fish Biology, 30, 263-271.

178. Weber, W., Jenning, C. A., \& Rogers, S. G. (1998). Population size and movement patterns of shortnose sturgeon in the Ogeechee River system, Georgia. Proc. Ann. Conf. Southeast Assoc. Fish and Wildl. Agencies, 52, 18-28.

179. Webb, M. A., Doroshov, S. I., \& Van Eenennaam J. P. (1994). Effects of temperature on final ovarian maturation in white sturgeon (Acipenser transmontanus). Proc. Intern. Fish. Physiol. Symp. Fish Physiol. Ass. Vancouver, Canada, 186-190.

180. Williot, P., Bronsi, P., \& Arlati, G. (1999). A very brief survey of status and prospects of freshwater sturgeon farming. EAS, Spesial Publication, 20, 32-36.

181. Williot, P. (2005). Attempts at larval rearing of the endangered western European Strugeon, (Acipenser sturio) in France. Cybiun, 29, 381-387.

182. Williot, P., Arlati, G., \& Chebanov, M. S. (2002). Status and management of Eurasian sturgeon: overview. International Review of Hydrobiology, 87, 483-506.

183. Williot, P., \& Brun, R. (1998). Ovarian development and cycles in cultured Siberian sturgeon (Asipenser baeri). Aquatic Living Resources, 11, 111-118.

184. Wong, Y. L., \& Binkowski, F. P. (1985). Effect of temperature on early development of white and lake sturgeon Acipenser transmontanus and $A$. fulvescens. Environmental Biology of Fishes, 14, 43-50.

185. Xie, D., Tiang, Y., \& Chen, D. (1992). Study of domestication of the shanjiang sturgeon in pond. Proceeding Intern. symp. on sturgeons and paddlefishes. Chonqing, China, 6-7.

186. Zhu, Y., Wei, Q., \& Yang, D. (2006). Large-scale cultivation of fingerlings of the Chinese Sturgeon (Acipenser sinensis) for re-stocking: a description of current technology. Journal of Applied Ichthyology, 22, 238-243.

187. Zhuang, P., \& Yi, J. (1999). Sturgeon and paddlefish aquaculture in China. Journal of Applied Ichthyology, 15, 3-34. 